\title{
Analisis Kelayakan Pengembangan Sistem Informasi Pelaporan Standar Pelayanan Minimal Rumah Sakit Berbasis Web
}

\author{
Kori Puspita Ningsih ${ }^{1}$ dan Sigid Nugroho Adhi ${ }^{2}$ \\ 1,2Fakultas Kesehatan, Universitas Jenderal Achmad Yani Yogyakarta, Indonesia \\ puspitakori@gmail.com ${ }^{1}$ dan hanyasigid@gmail.com²
}

Diajukan 13 Oktober 2020 Diperbaiki 1 Desember 2020 Diterima 17 Desember 2020

\section{ABSTRAK}

\begin{abstract}
Latar Belakang: Pelaporan Standar Pelayanan Minimal RS di RSUD Panembahan Senopati Bantul masih dilakukan secara konvensional. Oleh karena itu perlu dilakukan pengembangan sistem informasi, supaya data dapat diakses secara real time, kapanpun dan dimanapun. Analisis kelayakan merupakan bagian vital pada tahap perancangan sistem informasi. Dokumen feasibility tersebut digunakan sebagai acuan organisasi untuk menentukan kelanjutan dari suatu proyek.

Tujuan: Menganalisis kelayakan sistem informasi pelaporan Standar Pelayanan Minimal RS berbasis web dari aspek teknis, ekonomi, dan organisasi.

Metode: Penelitian ini menggunakan deskriptif, dengan pendekatan pengumpulan data kualitatif. Pengambilan data dengan observasi, wawancara dan studi dokumentasi. Untuk menjamin validitas data dilakukan triangulasi sumber.

Hasil: Hasil analisis kelayakan menunjukkan bahwa RSUD Panembahan Senopati Bantul memiliki perangkat keras, perangkat lunak dan jaringan yang layak untuk mendukung pengembangan sistem informasi pelaporan Standar Pelayanan Minimal RS berbasis web dengan nilai feasibilty sebesar 77,06. Hasil analisis kelayakan ekonomi diperoleh nilai Payback Payment (PP) 0,97, Return of investment (ROI) $4,18>0$, dan Net Present Value (NPV) > 0, dengan nilai feasibility sebesar 100 dan nilai feasibility organisasi sebesar 93,33, sehingga diperoleh rata-rata nilai feasibilty sebesar 90,13.

Kesimpulan: Hasil analisis kelayakan secara teknis, ekonomi dan organisasi menunjukkan RSUD Panembahan Senopati Bantul layak untuk dilakukan pengembangan sistem informasi pelaporan Standar Pelayanan Minimal RS berbasis web.
\end{abstract}

Kata Kunci: Analsisis; Kelayakan; Sistem informasi; Standar pelayanan minimal rumah sakit; Web

\section{ABSTRACT}

Background: Hospital SPM reporting at Panembahan Senopati Bantul Hospital is still done conventionally. Therefore, it is necessary to develop an information system, so that data can be accessed in real time, anytime and anywhere. Feasibility analysis is a vital part of the information system design stage. The feasibility document is used as a reference for the organization to determine the continuation of a project.

Objective: Analyze the feasibility of a web-based Hospital Minimum Service Standard (SPM RS) reporting information system from technical, economic, and organizational aspects.

Method: This study used descriptive research with a qualitative data collection approach. Content analysis is used to analyze qualitative data.

Results: The results of the feasibility analysis at Panembahan Senopati Bantul Hospital have the proper hardware, software, and network to support the development of a web-based RS SPM reporting information system with a feasibility value of 77.06. The results of the economic feasibility analysis show that the Payback Payment (PP) value is 0.97, Return on investment (ROI) is 4.18>0, and Net Present Value (NPV)>0, with a feasibility value of 100 and an organization's feasibility value of 93.33., so that the average feasibility value is 90.13.

Conclusion: The technical, economic, and organizational feasibility analysis results show that the Panembahan Senopati Bantul Regional Hospital is feasible to develop a web-based SPM RSUD reporting information system.

Keywords: Analysis; Feasibility; Information systems; Minimum hospital service standards; The web 
PENDAHULUAN

Kemajuan teknologi informasi berpengaruh terhadap berbagai bidang kehidupan manusia termasuk bidang kesehatan (Permenkes No. 46 Tahun 2014). Teknologi informasi memiliki peran penting dalam pelayanan kesehatan saat ini, dimana kualitas pengolahan informasi merupakan faktor penting bagi keberhasilan institusi pelayanan kesehatan (Hariana et al., 2013). Berbagai aplikasi sistem informasi sudah dibuat dan dikembangkan untuk menunjang kegiatan pengelolaan data kesehatan di fasilitas pelayanan kesehatan, salah satunya di rumah sakit.

Sistem informasi di rumah sakit memiliki peran penting dalam meningkatkan sharing informasi kesehatan. Selain itu sistem informasi juga akan meningkatkan keuntungan rumah sakit, meningkatkan kualitas pelayanan, dan menghemat biaya rumah sakit (Vest $e t$ al., 2012). Hasil penelitian sebelumnya juga menunjukkan ada hubungan antara penggunaan sistem informasi dengan efisiensi pelayanan, kepuasan pasien, dan kualitas pelayanan di rumah sakit (Fichman et al., 2011).

Rumah sakit sebagai BLUD mempunyai kewajiban membuat dan menyampaikan dokumen sebagai syarat administrasi, yang salah satunya adalah Standar Pelayanan Minimal (SPM) (Permendagri No. 61 Tahun 2007). SPM merupakan ketentuan tentang jenis dan mutu pelayanan dasar urusan wajib daerah yang berhak diperoleh setiap warga negara secara minimal (Permenkes No. 129 Tahun 2008). Hal ini juga sesuai dengan peran rumah sakit sebagai BLUD, yang setiap semester dan tahunannya wajib menyusun dan menyampaikan laporan keuangan lengkap yang terdiri dari laporan operasional, neraca, laporan arus kas dan catatan atas laporan keuangan disertai laporan kinerja kepada PPKD untuk dikonsolidasikan ke dalam laporan keuangan pemerintah daerah, paling lambat 2 (dua) bulan setelah periode pelaporan berakhir (Permendagri No. 61 Tahun 2007).

Adanya SPM RS sebagai tolok ukur mutu pelayanan rumah sakit juga tertuang pada SNARS Bab PMKP 6 yang menjelaskan bahwa setiap unit kerja di RS memilih dan menetapkan indikator mutu yang dipergunakan untuk mengukur mutu unit kerja. Indikator mutu unit kerja tersebut dapat menggunakan indikator mutu yang tercantum di dalam SPM (KARS, 2018). Penelitian sebelumnya menunjukkan dampak implementasi SPM RS yang baik berpengaruh terhadap peningkatan kinerja keuangan yang cukup signifikan (Sufiati et al., 2013).

Saat ini rumah sakit di Indonesia melaporkan SPM RS kepada Pemerintah Daerah secara konvensional dan belum ada umpan balik kualitas informasi dari Pemerintah Daerah kepada rumah sakit.

Penggunaan Sistem Informasi Manajemen Rumah Sakit (SIMRS) di Daerah Istimewa Yogyakarta (DIY) mayoritas digunakan untuk fungsi administrasi yang berupa pendaftaran pasien elektronik $(79,17 \%)$ dan billing system (70,83\%) (Hariana et al., 2013).

RSUD Panembahan Senopati Bantul merupakan rumah sakit umum tipe $B$ di wilayah DIY, yang merupakan rumah sakit milik Pemerintah Kabupaten Bantul. RSUD Panembahan Senopati Bantul memberikan pelayanan spesialis dan menerima pelayanan rujukan bagi masyarakat di sekitar wilayah Kabupaten Bantul dan sekitarnya.

Dari segi penjaminan mutu, pada tahun 2016 RSUD Panembahan Senopati Bantul telah terakreditasi penuh dengan predikat paripurna bintang lima. Dengan adanya kondisi tersebut, diharapkan RSUD Panembahan Senopati Kabupaten Bantul dapat menunjukkan akuntabilitasnya dengan senantiasa memenuhi SPM.

Berdasarkan studi pendahuluan dengan melakukan wawancara kepada 
Kepala Bidang Keperawatan dan Mutu yang merupakan penanggungjawab laporan SPM RS, diperoleh hasil bahwa SPM RS wajib dibuat sebagai syarat administrasi BLUD dan merupakan "janji" kepada pasien dan masyarakat. RSUD Panembahan Senopati Bantul telah menggunakan Sistem Informasi Manajemen Rumah Sakit (SIM RS) sejak tahun 2012, akan tetapi dalam hal pelaporan SPM RS masih dilakukan secara kovensional. Fitur pada SIM RS belum memenuhi kebutuhan output untuk pelaporan SPM RS. Pada 21 unit pelayanan, minimal ada 2 orang yang terlibat dalam pengumpulan data SPM RS yaitu, penanggungjawab mutu dan kepala unit kerja.

Sistem yang masih konvensional tersebut menimbulkan banyak permasalahan di rumah sakit, meliputi pimpinan rumah sakit tidak dapat mengakses informasi secara cepat, ketidaklengkapan informasi yang dihasilkan, dan rentan terjadinya kehilangan data karena tersimpan di banyak tempat. Pengelolaan data secara konvensional juga mempunyai banyak kelemahan, selain membutuhkan waktu yang lama dalam kegiatan pengumpulan, pengolahan dan penyajian data, keakuratannya juga kurang dapat diterima karena kemungkinan kesalahan yang sangat besar (Ningsih et al., 2019). Oleh karena itu perlu dilakukan pengembangan sistem informasi pelaporan SPM RS berbasis web, dengan tujuan sistem dapat diaksses oleh pihak RS, Dinas Kesehatan Bantul, Bupati Bantul dan masyarakat secara real time, kapanpun dan dimanapun sesuai otorisasi masing-masing.

Kegiatan menyusun sistem baru untuk menggantikan sistem lama secara keseluruhan maupun memperbaiki sistem yang telah ada dapat diartikan sebagai kegiatan mengembangkan sistem informasi. Pengembangan sistem informasi dilakukan karena banyaknya permasalahan (problem) yang timbul pada sistem yang sedang digunakan. Alasan lain yang mendasari perlunya dilakukan pengembangan sistem informasi adalah karena adanya kesempatan (opportunity), dimana dengan adanya perkembangan organisasi maka perlu didukung pula dengan perkembangan teknologi informasi untuk menyediakan informasi sebagai bahan pengambilan keputusan. Tuntutan masyarakat, keluhan pelanggan, ketidakteptan waktu penyediaan laporan, ketidakakuratan laporan serta tidak efisiennya pekerjaan juga menjadi hal mendasar adanya pengembangan sistem informasi (Dennis et al., 2012).

Salah satu metode pengembangan sistem informasi adalah System Development Life Cycle (SDLC). SDLC merupakan rangkaian proses menentukan bagaimana sistem informasi dapat mendukung kebutuhan bisnis, merancang sistem, membangunnya dan memberikannya kepada pengguna (Coronel et al., 2011; Pressman, 2012). Metode SDLC sudah secara luas dipergunakan untuk pengembangan software (Permenkominfo No. 41 Tahun 2007; Syamsiyah \& Sesunan, 2018).

Tahapan pengembangan SDLC meliputi perencanaan, analisis, desain, dan implementasi (Rahayu et al., 2017; Syamsiyah \& Sesunan, 2018). Perencanaan merupakan tahap pertama dalam perancangan sistem ini, yakni melakukan observasi terhadap proses bisnis perusahaan, kemudian melakukan wawancara untuk mengidentifikasi sistem yang dibutuhkan dan dilanjutkan analisis kelayakan (feasibility analysis) sistem yang akan dikembangkan. Analisis kelayakan sistem mencakup bidang teknis, ekonomi dan operasional (Dennis et al., 2012; Widianto \& Syaifullah, 2014).

Analisis kelayakan merupakan bagian vital pada tahap perancangan sistem informasi. Analisis kelayakan digunakan sebagai acuan organisasi untuk menentukan kelanjutan dari suatu proyek 
Analisis Kelayakan Pengembangan Sistem Informasi Pelaporan...

(Phillips, 2010). Tujuan dari penelitian ini adalah menganalisis kelayakan sistem informasi pelaporan Standar Pelayanan Minimal Rumah Sakit (SPM RS) berbasis web dari aspek teknis, ekonomi, dan organisasi.

\section{METODE}

Pendekatan kualitatif digunakan untuk mendeskripsikan hasil analisis kelayakan sistem informasi pelaporan SPM RS berbasis web. Pendekatan kualitatif digunakan untuk menggali kelayakan sistem informasi pelaporan SPM RS berbasis web dari aspek teknis, ekonomi, dan organisasi.

Lokasi penelitian ini akan dilaksanakan di Rumah Sakit Umum Daerah (RSUD) Panembahan Senopati Bantul. Waktu penelitian ini dilaksanakan pada bulan Juli sampai September 2020.

Metode pengumpulan data pada penelitian ini melalui pengamatan (observasi) dan wawancara mendalam (indepth interview) kepada Kepala Bidang Keperawatan dan Mutu, serta 21 koordinator mutu di masing-masing unit di RSUD Panembahan Senopati Bantul. Dari hasil wawancara mendalam didapatkan data primer terkait alur pelaporan SPM RS, menggali masalah yang dihadapi pada kegiatan pelaporan SPM RS, kebutuhan dan kelayakan pengembangan sistem informasi laporan SPM RS. Data sekunder dihimpun dari Kebijakan, Surat Keputusan, Pedoman, Standar Prosedur Operasional (SPO), dan laporan-laporan SPM RS yang diperoleh dengan cara review dokumen.

Untuk menjaga validitas data kualitatif, digunakan metode triangulasi. Triangulasi sumber digunakan untuk mencocokkan informasi hasil wawancara seluruh informan dengan informasi dari informan triangulasi yaitu Kepala Seksi Mutu dan Audit Klinik dan Dewan Pengawas RS Kabupaten Bantul. Triangulasi teknik dengan cara membandingkan hasil wawancara, hasil observasi, dan studi dokumentasi. Triangulasi waktu dengan cara menanyakan pertanyaan yang sama pada orang yang sama tetapi waktunya berbeda dan diharapkan diperoleh hasil yang sama pula.

Realibilitas instrumen penelitian kualitatif dilakukan dengan cara ketua dan anggota peneliti mendengarkan selama beberapa kali rekaman audio oleh orang yang berbeda atau sama, atau mempelajari transkripsi hasil rekaman berulang-ulang yang dilakukan oleh orang yang sama atau berbeda (Sugiyono, 2014). Setelah data alur pelaporan SPM RS, data identifikasi masalah, kebutuhan pelaporan SPM RS berbasis teknologi tersebut dinyatakan valid, maka peneliti melanjutkan menganalisis kelayakan pelaporan SPM RS berbasis teknologi informasi.

Selanjutnya, peneliti melakukan analisis data menggunakan analisis isi, dengan cara menganalisis komunikasi secara sistematik, obyektif terhadap pesan yang terlihat. Data hasil wawancara mendalam, observasi dan studi dokumentasi dipilih menurut relevansinya untuk selanjutnya disajikan dalam bentuk narasi.

\section{HASIL DAN PEMBAHASAN}

\section{Kelayakan Teknis}

Kelayakan teknis pada penelitian ini digunakan untuk menganalisis kebutuhan pengembangan sistem informasi pelaporan SPM RS berbasis web di RSUD Panembahan Senopati Bantul. Analisis kelayakan teknis dilakukan untuk mendata semua komponen yang berhubungan dengan teknologi pendukung sistem (Rahayu et al., 2017).

Sistem informasi pelaporan SPM RS merupakan sebuah sistem berbasis web yang digunakan untuk kegiatan reporting, membantu dan mempermudah proses pengumpulan, pengolahan dan penyajian laporan SPM RS dari 21 penanggung jawab mutu unit, Kepala Seksi Mutu dan 
Analisis Kelayakan Pengembangan Sistem Informasi Pelaporan...

Audit Klinik, Kepala Bidang Keperawatan dan Mutu, Top Managemen, Bupati, Dinas Kesehatan dan masyarakat. Hal tersebut tentu membutuhkan komputer personal dan infrastruktur jaringan komputer yang baik. Hal tersebut berguna untuk meningkatkan kualitas informasi SPM RS, baik penyimpanan big data SPM RS yang tersentral dalam suatu basis data maupun efektifitas kerja petugas.

\section{a. Perangkat Keras (Hardware)}

Berikut ketersediaan perangkat keras di RSUD Panembahan Senopati Bantul (Tabel 1):

Tabel 1. Perangkat Keras

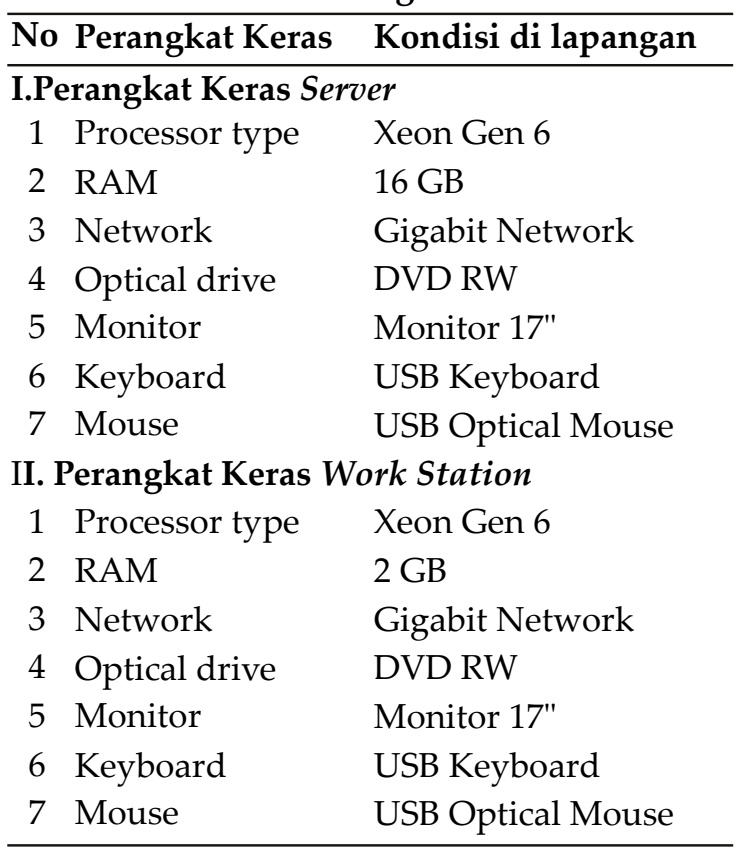

Berdasarkan tabel 1 dapat diartikan bahwa RSUD Panembahan Senopati Bantul memiliki server untuk menyimpan salinan data dengan aman. Akan tetapi, saat ini server belum dioptimalkan untuk penyimpanan data pelaporan SPM RS. Secara infrastruktur, pada 21 unit pelayanan juga di dukung dengan penyediaan komputer dan printer di setiap unit penanggung jawab mutu (spesifikasi workstation pada tabel 1), server terpusat dengan pengelolaan dibawah Unit IT. Suatu sistem komputer yang menyediakan banyak layanan tertentu berupa program aplikasi, sistem operasi, maupun data-data kepada komputer lain yang saling berhubungan pada suatu jaringan komputer disebut dengan server (Rahmatulloh \& MSN, 2017).

b. Perangkat Lunak (Software)

Berikut ketersediaan perangkat lunak di RSUD Panembahan Senopati Bantul (Tabel 2):

Tabel 2. Perangkat Lunak

\begin{tabular}{cll}
\hline No & Perangkat Lunak & Kegunaan \\
\hline 1 & Windows 10 & Sistem Operasi \\
2 & Php, HTML & $\begin{array}{l}\text { Pembuatan web } \\
\text { sistem }\end{array}$ \\
3 & Photo Shop. CS 3 & Design Web sistem \\
4 & Dream Weaver. CS & Design Web sistem \\
5 & Microsoft visio Pro & Perancangan Sistem \\
6 & Internet Explorer & Web Browser \\
7 & XAMPP & Web Server \\
8 & My SQL Server & Database Server \\
\hline
\end{tabular}

Berdasarkan tabel 2, diketahui bahwa dengan adanya XAMPP yang berguna sebagai web server, PHP dan HTML sebagai pembuatan web sistem dan MySQL Server sebagai database server mampu mendukung penegmbangan sistem informasi pelaporan SPM RS berbasis web. Untuk membangun sistem informasi manajemen rumah sakit berbasis web, diperlukan bahasa pemograman seperti HTML,CSS, PHP dan Javascript (Topan et al., 2015).

Perangkat lunak pendukung yang digunakan untuk menyimpan data atau file pelaporan SPM RS di RSUD Panembahan Senopati Bantul adalah Microsoft Exccel dan Microsoft Word. Sekumpulan file yang saling berkaitan, berinteraksi, dan berelasi dengan menunjukkan kunci dari setiap file yang ada disebut dengan database. Database berguna untuk mengatasi permasalahan dalam pengolahan data seperti redudansi data, keamanan data, kesulitan mengakses data dan isolasi data untuk standarisasi (Sovia \& Febio, 2011).

Database yang digunakan di RSUD Panembahan Senopati Bantul tersebut belum terintegrasi dengan baik, proses input data dan akses data dilakukan dengan pencarian secara manual bukan 
Analisis Kelayakan Pengembangan Sistem Informasi Pelaporan...

searching sistem. Hal ini berisiko rentan terjadi kesalahan input data, kerusakan file karena virus dan kehilangan data karena data belum terbackup di server, karena itu perlu dilakukan pengembangan sistem informasi pelaporan SPM RS berbasis web untuk mengintegrasikan dan mengamankan data.

Sistem informasi mampu mengamankan data karena data tersalin di server, akses mudah karena sistem yang menjalankan dan user hanya menginputkan data (Widianto \& Syaifullah, 2014).

Berikut arsitektur aplikasi sistem informasi pelaporan SPM RS berbasis web di RSUD Panembahan Senopati Bantul (Gambar 1):

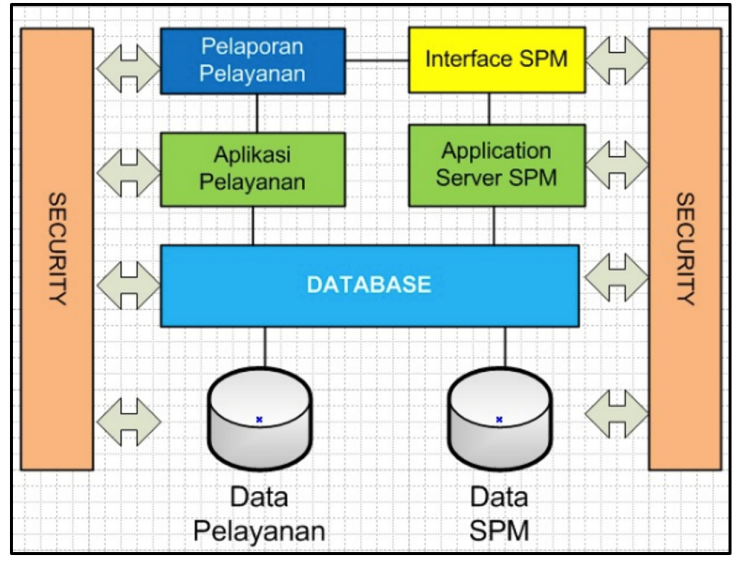

Gambar 1. Arsitektur Aplikasi

Pada gambar 1, dapat disampaikan bahwa database akan menyimpan data SPM dan data pelayanan. Data pelayanan tersebut diperoleh dari aplikasi pelayanan yang saat ini digunakan oleh rumah sakit, dengan menghasilkan ouput pelaporan pelayanan, dimana output pelaporan pelayanan akan diintegrasikan dengan aplikasi SPM. Untuk melindungi keamanan data, maka akan didukung dengan security, dimana setiap pengguna diberikan user dan password untuk dapat mengakses informasi SPM sesuai otorisasi masing-masing.

\section{c. Jaringan}

Selain perangkat keras dan perangkat lunak, peneliti juga menganalisis kelayakan teknis berdasarkan ketersediaan jaringan di RSUD Panembahan Senopati Bantul (Tabel 3):

Tabel 3. Perangkat Jaringan

\begin{tabular}{|c|c|c|}
\hline & Perangkat Jaringan & Kegunaan \\
\hline 1 & Switch & $\begin{array}{l}\text { Penghubung kabel- } \\
\text { kabel jaringan dari } \\
\text { setiap workstation }\end{array}$ \\
\hline 2 & Kabel UTP & Media penghubung \\
\hline 3 & Konektor RJ 45 & $\begin{array}{l}\text { Penghubung antar } \\
\text { kabel dengan LAN } \\
\text { Card }\end{array}$ \\
\hline
\end{tabular}

\begin{tabular}{|c|c|}
\hline $\begin{array}{l}\text { Jaringan } \\
\text { Panembahan }\end{array}$ & komputer di \\
\hline
\end{tabular}
menggunakan Local Area Network (LAN). LAN meruapakan sebuah jaringan komputer dalam jarak yang dekat, dalam arti masih berada pada suatu bangunan atau ruangan, dan memiliki kecepatan komunikasi data yang tinggi (Sovia \& Febio, 2011).

Jaringan internet dikelola oleh Unit TI sesuai kebutuhan masing-masing unit, sedangkan untuk wifi dilakukan pemisahan konektifitas menjadi 3 kriteria, yaitu pengunjung/umum, pegawai dan top managemen termasuk tamu undangan (jika ada). Berikut arsitektur jaringan sistem informasi pelaporan SPM RS berbasis web di RSUD Panembahan Senopati Bantul (gambar 2):

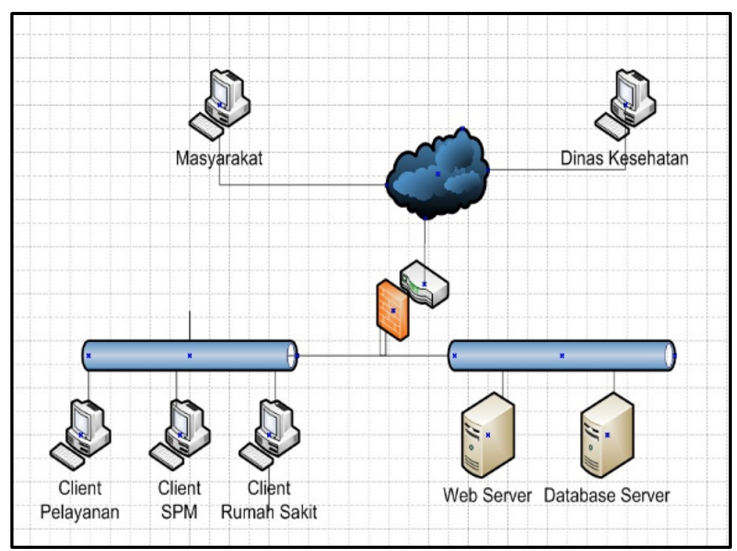

Gambar 2. Arsitektur Jaringan

Pada gambar 2 dapat disampaikan bahwa apabila user meminta suatu informasi maka akan bertindak sebagai client, dimana web informasi disimpan pada komputer yang disebut sebagai server. Selanjutnya, permintaan informasi akan disampaikan kepada server dan server akan mencari apakah informasi 
yang diminta tersedia di database atau tidak, apabila infomasi yang diminta tersedia, maka server akan memberikan informasi tersebut ke user.

Dalam hal kelayakan teknis, RSUD Panembahan Senopati juga menyediakan listrik yang cukup untuk operasional rumah sakit, dengan dilengkapi gendset. Dengan demikian dapat disampaikan bahwa RSUD Panembahan Senopati Bantul memiliki perangkat keras, perangkat lunak dan jaringan yang layak untuk mendukung pengembangan sistem informasi pelaporan SPM RS berbasis web.

\section{Kelayakan Ekonomi}

Kelayakan ekonomi pengembangan sistem informasi pelaporan SPM RS berbasis web digunakan untuk menganalisis biaya dan manfaat, memberikan gambaran apakah sistem informasi pelaporan SPM RS berbasis web yang akan dikembangkan memiliki manfaat lebih besar dibandingkan dengan biaya yang akan dikeluarkan oleh RSUD Panembahan Senopati Bantul. Kelayakan ekonomi menjelaskan analisis biaya dan manfaat, untuk mengetahui apakah manfaat yang akan diperoleh dari dari sistem yang akan dikembangkan lebih besar dibandingkan dengan biaya yang akan dikeluarkan (Rahayu et al., 2017).

Pada analisis biaya dan manfaat, ada beberapa metode kuantitatif yang digunakan untuk menemukan standar kelayakan proyek (Widianto \& Syaifullah, 2014). Analisis biaya dan manfaat pada pengembangan sistem informasi pelaporan SPM RS berbasis web di RSUD Panembahan Senopati Bantul terdiri dari:

a. Analisis Biaya

Analisis biaya yang berkaitan dengan pengembangan sistem informasi pelaporan SPM RS berbasis web meliputi biaya pengembangan, yaitu biaya pembuatan perangkat lunak sistem informasi pelaporan SPM RS berbasis web yang meliputi biaya konsultasi di tahap perencanaan, analisis kebutuhan, design arsitektur dan produk, pembuatan produk, testing dan debugging serta instalasi; biaya operasi dan maintanance yang meliputi biaya yang digunakan untuk operasional sistem, yaitu biaya overhead dan biaya maintanance, sedangkan menurut Widianto \& Syaifullah (2014) analisis biaya yang berhubungan dengan pembuatan sistem diklasifikasikan dalam 3 kategori utama, yaitu biaya pengadaan, biaya pengembangan serta biaya operasi dan perawatan.

b. Analisis Manfaat

Manfaat yang diperoleh dari pengembangan sistem informasi pelaporan SPM RS berbasis web, meliputi keuntungan berwujud (tangible benefit) dan keuntungan tidak berwujud (intangible benefit). Dengan adanya pengembangan sistem ini, diharapkan RSUD Panembahan Senopati Bantul mendapatkan keuntungan berwujud berupa penghematan dan peningkatan proses administrasi yang dapat diukur dalam satuan nilai uang. Keuntungan tersebut berupa pengurangan biaya ATK untuk kebutuhan pembuatan laporan yang sebelumnya menggunakan kertas, pengurangan biaya SDM dan pengurangan biaya operasional sehingga meningkatkan efektifitas proses kerja. Keuntungan tak berwujud merupakan keuntungan yang sulit atau tidak dapat diukur dalam satuan nilai uang, Keuntungan tersebut berupa ketersediaan kebutuhan data secara realtime dan akurat, efektifitas kinerja pegawai dan kepuasan pengguna dengan pemanfaatan sistem baru.

Adapun metode analisis biaya dan manfaat yang digunakan untuk menilai kelayakan ekonomi pengembangan sistem informasi pelaporan SPM RS berbasis web meliputi:

a) Payback Period (PP)

Payback Period (PP) merupakan suatu uji kuantitatif yang digunakan untuk menghitung jangka waktu yang 
diperlukan untuk mengembalikan biaya investasi yang dikeluarkan untuk pembuatan aplikasi. Perhitungn PP pada suatu proyek dinilai layak apabila waktu pengembalian lebih kecil dari umur investasi, sedangkan tidak layak apabila waktu pengembalian lebih besar dari umur investasi. Adapun perhitungan dari PP yaitu (Widianto \& Syaifullah, 2014):

Periode $=\frac{\text { investasi }}{\text { proses }} \times$ tahun

Periode $=\frac{153.420 .000}{156.760 .000} \times 1$

Periode $=0.97$

Berdasarkan perhitungan PP tersebut dapat disampaikan bahwa pengembalian dana dapat dicapai pada tahun ke-1, dalam arti perancangan sistem informasi pelaporan SPM RS akan mencapai titik impas pada kurun waktu kurang lebih anatara 9 sampai 10 bulan. Hal ini menunjukkan keuntungan dari sistem akan diperoleh setelah bulan ke-10.

Dengan demikian sistem informasi pelaporan SPM RS berbasis web layak dikembangkan, karena waktu pengembalian lebih kecil dari umur investasi.

b) Return on Investment

Metode Return on Investment (ROI) digunakan untuk mengukur presentase manfaat yang dihasilkan proyek dibanding dengan biaya yang dikeluarkan. Penilaian kelayakan ROI, dinyatakan layak jika ROI $>0$ dan tidak layak jika ROI < 0 (Ningsih et al., 2019; Widianto et al., 2014). Berikut nilai biaya yang dibutuhkan untuk sistem informasi pelaporan SPM RS berbasis web (Tabel 4 ):

Tabel 4. Nilai Biaya

\begin{tabular}{clr}
\hline Tahun & \multicolumn{2}{c}{ Biaya } \\
\hline Ke-0 & 1. Pembuatan sistem & 147.000 .000 \\
& 2. Instalasi dan Serah & 2.610 .000 \\
& Terima & \\
& 3. Pelatihan Pengguna & 3.690 .000 \\
Ke-1 & 1. Maintenan sistem & 6.000 .000 \\
& 2. Rapat Evaluasi & 1.750 .000 \\
& sistem & \\
& 3. Perbaikan sistem & 10.000 .000 \\
& 4. Pelatihan pengguna & 3.690 .000 \\
\hline
\end{tabular}

$\begin{array}{lll}\text { Ke-3 } & \begin{array}{l}\text { 1. Maintenance sistem } \\ \text { 2. Rapat Evaluasi } \\ \text { sistem }\end{array} & 6.000 .000 \\ & \end{array}$

Total

188.610.000

Berdasarkan tabel 4, dapat diketahui bahwa pada tahun ke-0 membutuhkan biaya $\mathrm{Rp}$ 153.420.000,- untuk pengembangan sistem informasi pelaporan SPM RS berbasis web di RSUD Panembahan Senopati Bantul, meliputi pembuatan sistem (mulai dari tahap perencanaan, mendefinisikan kebutuhan, design arsitektur produk, pembuatan product, testing dan debugging), instalasi dan serah terima. Pada tahun ke-1 membutuhkan biaya $\mathrm{Rp}$ 21.440.000,untuk maintanance, rapat evaluasi, perbaikan sistem, pelatihan pengguna dan tahun ke-2 membutuhkan biaya Rp 13.750.00,- untuk maintanance dan rapat evaluasi, sehingga total kebutuhan biaya pengembangan sistem sebesar Rp 188.610.00,-.

Berikut nilai manfaat yang dibutuhkan untuk sistem informasi pelaporan SPM RS berbasis web (Tabel 5):

Tabel 5. Nilai Manfaat

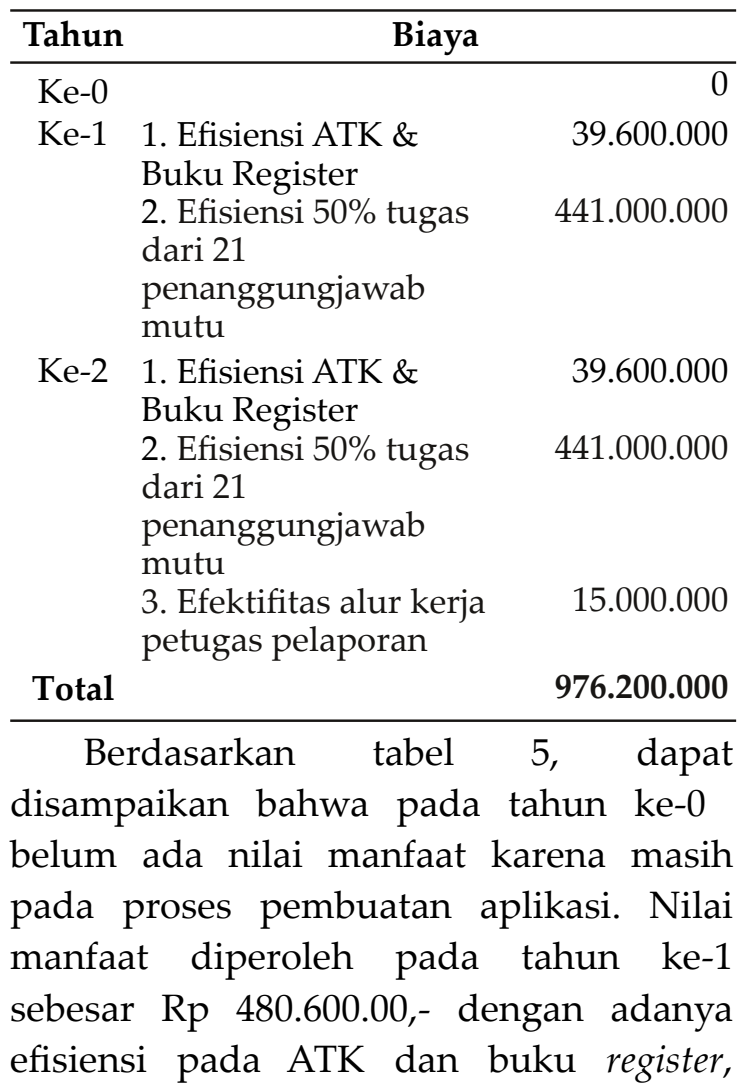


efisiensi 50\% tugas dari 21 penanggung jawab dengan asumsi gaji Rp 3.500.000,perbulan, sehingga efisiensi $50 \%$ petugas dalam 1 tahun sebesar $\operatorname{Rp} 441.000 .000,-$. Nilai manfaat pada tahun ke-2 sebesar $\mathrm{Rp}$ 495.000.000,- dengan adanya efisiensi ATK dan buku register, efisiensi 50\% tugas dari 21 penanggung jawab dan efektifitas alur kerja pertugas pelaporan karena sudah terbiasa menggunakan sistem informasi SPM RS yang dikembangkan.

Selanjutnya, dari nilai biaya dan manfaat akan diperoleh perhitungan ROI (Widianto \& Syaifullah, 2014):

$$
\begin{aligned}
& \text { ROI }=\frac{\text { Total manfaat }- \text { Total biaya }}{\text { total biaya }} \times 100 \% \\
& \text { ROI }=\frac{188.610 .000-976.200 .000}{976.200 .000} \times 100 \% \\
& \text { ROI }=4,18
\end{aligned}
$$$$
\text { Hasil perhitungan ROI 4,18, }
$$
menunjukkan $4,18>0$, artinya pengembangan sistem informasi pelaporan SPM RS berbasis web layak dikembangkan.

\section{c) Net Present Value (NPV)}

NPV adalah metode yang memfokuskan pada nilai waktu dari uang. Suku bunga mempengaruhi aliran uang. NPV dapat dihitung dengan negatif investasi biaya ditambah dengan proses setiap tahun yang dikonversi ke present value sesuai suku bunga. NPV dikatakan layak jika NPV $>0$, atau NPV $=0$ dan dinyatakan tidak layak jika NPV $<0$ (Widianto \& Syaifullah, 2014). Hasil perhitungan nilai NPV pada sistem informasi pelaporan SPM RS berbasis web adalah sebagai berikut:

$$
\mathrm{NPV}=- \text { investasi }+\frac{\text { Proses } 1}{(1+i) \ldots i^{2}}+\frac{\text { Proses } 2}{(1+i) \ldots i^{2}}
$$

Dimana:

$$
\begin{aligned}
& \mathrm{i}=\text { interrest rate } \\
& \text { proses }=\text { benefit }- \text { cost }
\end{aligned}
$$

$$
\begin{aligned}
\mathrm{NPV}=-152.420 .000+\frac{459.160 .000}{(1+0,065) ! 1} \\
+\frac{487.850 .000}{(1+0.065) \cdots \mathrm{i}^{2}}
\end{aligned}
$$

$\mathrm{NPV}=709.441 .814$
Pada perhitungan NPV tersebut nilai waktu suku bunga yang ditanamkan sebesar 6,5\% (berdasarkan suku bunga dari www.bi.go.id pada tanggal 10 Oktober 2020). Pada tahun ke-2 nilai NPV sebesar Rp 709.441.814,- dengan demikian dapat disampaikan investasi layak karena $\mathrm{NPV}>0$, yang menunjukkan investasi menguntungkan dan dapat diterima.

Untuk menilai kelayakan ekonomi dapat dilakukan dengan menggunakan Payback Period, Net Present Value, Interest Rate of Return dan Return on Investment (Rahayu et al., 2017). Adapun menurut Widianto \& Syaifullah (2014) kelayakan ekonomi dapat dinilai secara kuantitaif melalui Payback Period, Net Present Value, dan Return on Investment.

\section{Kelayakan Organisasi}

Hasil analisis kelayakan organisasi menunjukkan: (a) pengguna sudah terbiasa menggunakan sistem informasi untuk kegiatan entry data pelayanan billing system pasien, pengolahan data untuk pelaporan menggunakan excel; (b) pengguna memiliki keinginan untuk belajar jika ada sistem baru yang dikembangkan; (c) Ada dukungan dari manajemen untuk mengembangkan sistem informasi pelaporan SPM RS berbasis web. Kesiapan pengguna tersebut menjadi bahan pertimbangan dalam pengembangan sistem informasi pelaporan SPM GD berbasis web sehingga pada saat menerapkan sistem nantinya tidak terjadi permasalahan disisi sumber daya manusianya. Salah satu prinsip pengembangan sistem terpenting yang menjadi kajian bahasan adalah kebutuhan tenaga atau sumber daya manusia yang sudah terlatih. Faktor utama yang menentukan keberhasilan suatu sistem adalah faktor Sumber Daya Manusia (SDM), baik itu pada tahap pengembangan, penerapan, maupun pada tahap pengoperasiannya (Listiawati, 2018). 
Analisis Kelayakan Pengembangan Sistem Informasi Pelaporan...

Setelah melakukan analisis kelayakan teknis, ekonomi, dan operasional, maka selanjutnaya melakukan penilaian dari setiap kelayakan, yang meliputi 0 apabila not feasible, 50 untuk moderately feasible dan

0 : not feasible

Tabel 6. Nilai Analisis Kelayakan

50 : moderately feasible

100 : totally feasuble
100 untul totality feasibe (Rahayu et al., 2017). Berikut hasil penilaian kelayakan pengembangan sistem informasi pelaporan SPM RS berbasis web (Tabel 6):

\begin{tabular}{|c|c|c|c|c|c|}
\hline $\begin{array}{l}\text { Point } \\
\text { value }\end{array}$ & categories & Requirement & Capacity & Scale Score & $\begin{array}{c}\text { Feasibility } \\
\text { Score }\end{array}$ \\
\hline 100 & Technical Hardware & \multicolumn{4}{|c|}{ Penilaian berdasarkan hasil observasi } \\
\hline 5.88 & Processor type & 7 & 7 & 0.8 & 4.71 \\
\hline 5.88 & RAM & 7 & 7 & 0.7 & 4.12 \\
\hline 5.88 & Network & 7 & 7 & 0.8 & 4.71 \\
\hline 5.88 & Optical drive & 7 & 7 & 0.8 & 4.71 \\
\hline 5.88 & Monitor & 7 & 7 & 0.7 & 4.12 \\
\hline 5.88 & Keyboard & 7 & 7 & 0.7 & 4.12 \\
\hline \multirow[t]{2}{*}{5.88} & Mouse & 7 & 7 & 0.7 & 4.12 \\
\hline & Software & & & & \\
\hline 5.88 & Windows 10 & 7 & 7 & 0.8 & 4.71 \\
\hline 5.88 & PHP, HTML & 7 & 7 & 0.8 & 4.71 \\
\hline 5.88 & Microsoft visio & 7 & 7 & 0.8 & 4.71 \\
\hline 5.88 & Web server & 7 & 7 & 0.8 & 4.71 \\
\hline 5.88 & Web browser & 7 & 7 & 0.8 & 4.71 \\
\hline 5.88 & Desain web sistem & 7 & 7 & 0.8 & 4.71 \\
\hline \multirow[t]{2}{*}{5.88} & Database server & 7 & 7 & 0.8 & 4.71 \\
\hline & Perangkat Jaringan & & & & \\
\hline 5.88 & Switch & 5 & 5 & 0.8 & 4.71 \\
\hline 5.88 & Kabel UTP & 7 & 7 & 0.8 & 4.71 \\
\hline \multirow[t]{3}{*}{5.88} & Konektor RJ 45 & 7 & 7 & 0.8 & 4.12 \\
\hline & TOTAL & & & $100 /$ & 77.06 \\
\hline & Economic & \multicolumn{4}{|c|}{ Jika hasil perhitungan metode layak $=1$, jika tidak $=0$} \\
\hline 33.33 & Payback Period (PP) & 1 & 1 & 1 & 33.33 \\
\hline 33.33 & Return on Investment (ROI) & 1 & 1 & 1 & 33.33 \\
\hline \multirow[t]{3}{*}{33.33} & Net Present Value (NPV) & 1 & 1 & 1 & 33.33 \\
\hline & TOTAL & & & $100 /$ & 100.00 \\
\hline & Organizational & \multicolumn{4}{|c|}{ Penialaian berdasarkan hasil wawancara } \\
\hline 33.33 & $\begin{array}{l}\text { Kemampuan pegawai dalam } \\
\text { menggunakan komputer }\end{array}$ & 7 & 6 & 0.8 & 26.67 \\
\hline 33.33 & $\begin{array}{l}\text { Keinginan pegawai belajar } \\
\text { menggunakan sistem }\end{array}$ & 7 & 7 & 1 & 33.33 \\
\hline \multirow[t]{3}{*}{33.33} & Tingkat dukungan & 3 & 3 & 1 & 33.33 \\
\hline & TOTAL & & & $100 /$ & 93.33 \\
\hline & AVERAGE & & & & 90.13 \\
\hline
\end{tabular}


Berdasarkan hasil analisis kelayakan pada tabel 6, dapat disampaikan nilai kelayakan teknis sebesar 77,06, kelayakan ekonomi sebesar 100 dan kelayakan organisasi sebesar 93,33, sehingga diperoleh rata-rata nilai kelayakan (feasibilty) adalah 90,13.

\section{PENUTUP}

Hasil analisis kelayakan secara teknis, ekonomi dan organisasi menunjukkan RSUD Panembahan Senopati Bantul layak untuk dilakukan pengembangan sistem informasi pelaporan SPM RS berbasis web.

\section{DAFTAR PUSTAKA}

Coronel, C. M., Morris, S., \& Rob, P. (2011). Database Systems: Design, Implementation, and Management (Ninth Edit). Cengange Learning.

Dennis, A., Wixom, B. H., \& Roth, R. M. (2012). System Analysis and Design. In John Wiley $\mathcal{E}$ Sons, Inc. (5th ed.). John Wiley \& Sons, Ltd.

Fichman, R. G., Kohli, R., \& Krishnan, R. (2011). Editorial Overview - The Role of Information Systems in Healthcare: Current Research and Future Trends. Information Systems Research, 22(3), 419-428. https://doi.org/10.1287/isre. 1110.0382

Hariana, E., Sanjaya, G. Y., Rahmanti, A. R., Murtiningsih, B., \& Nugroho, E. (2013). Penggunaan Sistem Informasi Manajemen Rumah Sakit (SIMRS) di DIY. Open Acces Journal of Information System (OAJIS), 2013. http://is.its.ac.id/ pubs/oajis/index.php/home/detail/487/ Penggunaan-Sistem-InformasiManajemen-Rumah-Sakit-SIMRS-diDIY

KARS. (2018). Standar Nasional Akreditasi Rumah Sakit Edisi 1 (1st ed., pp. 1421). KARS. https://doi.org/10.15713/ ins.mmj.3

Listiawati, U. (2018). Analisis Efektivitas Sistem Informasi Akuntansi BULOG (SIAB) Dalam Menunjang Kinerja
Karyawan. EJournal Administrasi

Bisnis, 6(3), 881-891. https:// www.portal.fisip-unmul.ac.id/site/? $p=7780$

Ningsih, K. P., Agusyahbana, F., \& Sediyono, E. (2019). The Planning Of Technology-Based Emergency Minimum Service Standard Reporting System. The International Journal of Health, Education and Social (IJHES), 2(9), 36. https://doi.org/10.1234/ ijhes.v2i9.29

Peraturan Menteri Dalam Negeri No 61 tahun 2007 tentang Pedoman Teknis Pengelolaan Keuangan adan layanan Umum Daerah, 1 (2007).

Peraturan Menteri Kesehatan Republik Indonesia Nomor 46 Tahun 2014 tentang Sistem Informasi Kesehatan, Peraturan Menteri Kesehatan Republik Indonesia Nomor 46 Tahun 2014 tentang Sistem Informasi Kesehatan 1 (2014).

Peraturan Menteri Kesehatan Republik Indonesia Nomor 129 tahun 2008 Tentang Standar Pelayanan Minimal Rumah Sakit (2008).

Permenkominfo No 41/Per/Men.Kominfo/ 11/2007 tentang Panduan Umum Tata Kelola Teknologi Informasi dan Komunikasi Nasional, 1 (2007).

Phillips, J. (2010). IT Project Management: On Track from Start to Finish (3rd ed.). Mc Graw-Hill Higher Education.

Pressman, R. S. (2012). Rekayasa Perangkat Lunak - Buku Dua, Pendekatan Praktisi (Edisi 7) (Dhewiberta Hardjono (ed.); 7th ed.). Andi Yogyakarta.

Rahayu, P. C., Ishak, I., \& Makinto, E. (2017). Rekayasa Proses Bisnis Dengan Menggunakan Metode Iterative Sclc. Journal Industrial Manufacturing, 2(2), 50-61. http:// jurnal.umt.ac.id/index.php/jim/article/ view/626

Rahmatulloh, A., \& MSN, F. (2017). Implementasi Load Balancing Web Server menggunakan Haproxy dan Sinkronisasi File pada Sistem 
Informasi Akademik Universitas

Siliwangi. Jurnal Nasional Teknologi Dan Sistem Informasi, 3(2), 241-248. https://doi.org/10.25077/

TEKNOSI.v3i2.2017.241-248

Sovia, R., \& Febio, J. (2011). Membangun Aplikasi E-Library Menggunakan Html, Php Script, Dan Mysql Database. Jurnal Processor, 6(2), 38-54. http://ejournal.stikom-db.ac.id/ index.php/processor/article/view/28

Sufiati, A., Prasetyono, \& Kurniawan, F. A. (2013). Analisis dampak implementasi standar pelayanan minimal rumah sakit terhadap kinerja keuangan(studi pada RSUD DR. H. Moh. Anwar Sumenep). Jurnal InFestasi, 9(2), 103-114. https://doi.org/ 10.21107/infestasi.v9i2.548

Sugiyono. (2014). Metode Penelitian Kuantitatif Kualitatif dan RED. Alfabeta.

Syamsiyah, N., \& Sesunan, M. F. (2018). Penerapan Metode System Life Cycle Development Dan Project Management Body of Knowledge Pada Pengembangan Sistem Informasi. Ikraith-Informatika, 2(2). https://journals.upi-yai.ac.id/ index.php/ikraith-informatika/article/ view/163
Topan, M., Wowor, H. F., \& Najoan, X. B. N. (2015). Perancangan Sistem Informasi Manajemen Rumah Sakit Berbasis Web Studi Kasus: Rumah Sakit TNI AU Lanud Sam Ratulangi. E-Journal Teknik Informatika, 6(1), 1-6. https://ejournal.unsrat.ac.id/ index.php/informatika/article/ viewFile/9968/9554

Vest, J. R., Gamm, L. D., Ohsfeldt, R. L., Zhao, H., \& Jasperson, 'Jon. (2012). Factors Associated with Health Information Exchange System Usage in a Safety-Net Ambulatory Care Clinic Setting. Journal of Medical Systems, 36(4), 2455-2461. https:// doi.org/10.1007/s10916-011-9712-3

Widianto, J., Islam, U., Sultan, N., \& Kasim, S. (2014). Studi Kelayakan Sistem Informasi Akademik Berbasis Web. Jurnal Sains, Teknologi Dan Industri, Vol 11(No 2), 200-211.

Widianto, J., \& Syaifullah. (2014). Studi Kelayakan Sistem Informasi Akademik Berbasis Web Pada Poltekes Kemenkes Riau Dengan Menggunakan Metode Kelayakan Telos. SITEKIN: Jurnal Sains, Teknologi Dan Industri, Vol 11(No 2), 200-211. http://garuda.ristekbrin.go.id/ documents/detail/293915 